\title{
SELECTED ELEMENTS OF CHANGE MANAGEMENT AND BUSINESS PERFORMANCE OF MICROENTERPRISES
}

\author{
Karolina OKRĘGLICKA, Maryna PICHUGINA
}

\begin{abstract}
The change determines the development of all types of market institutions and organizations through the need to introduce innovative, modernizing and adaptive organizational solutions. Hence, organizational change cannot be separated from organizational strategy, and change management is a set of activities aimed at achieving the expected state in the organization. Change management is one of the elements of enterprise efficiency, therefore it should be implemented in all enterprises, regardless of their size. The aim of the article was to diagnose and evaluate selected aspects of change management in a microenterprise and to indicate the correlation between change management and the business performance of micro-enterprises. In order to achieve the set goal, the author conducted a survey in 2021 among micro-enterprises in Poland. The research confirmed the implementation of solutions for change management. The positive correlation between the elements of change management and the performance of enterprises was partially confirmed.
\end{abstract}

Key words:

micro-enterprises, strategy, change management, process approach, business performance

JEL classification: L26, M21

DOI: https://doi.org/10.52665/ser20210104

\section{INTRODUCTION}

The 21 st century has emphasized the need for the organization to respond to turbulence in the socio-economic environment by implementing effective change management. While the last decades of the 20th century are dominated by such management concepts as: quality management, benchmarking, reengineering and a learning organization, and then, knowledge and information management, more and more violent market crises, especially the financial crisis after 2008 and a deep crisis related to COVID-19 pandemic showed that enterprises have more and more problems with existing in the market, not to mention their development and achieving a high competitive position. Hence, change management has become one of the most popular and at the same time one of the most necessary trends in management sciences (Dziadkiewicz, Juchniewicz, 2013, pp. 15-23), and its effectiveness often determines the success or failure of the enterprise (Olejniczak, Nabiałek, 2015, pp. 17-24).
The aim of the article was to diagnose and evaluate selected aspects of change management in a microenterprise and to indicate the correlation between change management and the business performance of microenterprises. The article consists of the following parts: introduction, review of international literature in the field of change management, research methodology, results of own research and conclusions.

\section{Literature review}

Change is one of the main factors contributing to the development of man and entire civilization. It also determines the development of all types of market institutions and organizations, through the need to introduce innovative, modernizing and adaptive organizational solutions. According to Burnes (2004), change is a feature of life that is always present in an organization, both at the operational and strategic levels, therefore there should be no doubts as to the importance of the ability to determine for each organization where it is going in the future. as well as how to 
manage the required changes. As a consequence, organizational change cannot be separated from organizational strategy or vice versa (Rieley, Clarkson, 2001).

Change can be defined in many ways. Very generally, a change is defined by Clarke (1997, p. 242), who believes that it signifies a transition from the known to the unknown. On the other hand, Pszczołowski (1978, p. 289) accepts as a change a certain transition from the present to the future state, different from the initial one, which is made due to a specific feature in a specific period of time.

There are many possibilities of changes in systems and processes functioning in enterprises. Armstrong (2000, p. 70) in his research indicates that there are two types of changes in economic units: strategic and operational. The strategic change is always connected with the transformation of the company. It concerns problems of significant importance to the organization, which often translate into the overall functioning. Strategic changes also relate to a longer time perspective, and their assumptions are visible in the mission or goals of the organization. An example may be changes in the scope of improving the quality of products or services, development, innovation, technology, etc. Operational change is related to the day-today functioning of an enterprise and translates into the creation and modification of systems, procedures, structures or work organization. This type of changes is considered in a short period of time and has an immediate impact on the existing relationships within the organization.

The scope and reference of the changes is therefore very wide. They may take place at the individual, group or organizational level, they may concern the entire company or only selected specific areas of it. The division of organizational changes, which is very important for the enterprise, includes planned and adaptive changes. Planned change, ahead of future events, is introduced in a thoughtful and systematic manner. It is undertaken as a result of specific actions of decision-makers - people or groups actively promoting the process of change and managing its course (Schermerhorn 2008, p. 328 ). In the analysis of issues related to planned changes, the concept of efficiency gaps appears, defined as the difference between the desired state and the current state, or, in other terms, as the difference between the goals of a given organization and the results that this organization is able to achieve (Kulawik-Dutkowska, 2016). On the other hand, adaptive change is introduced ad hoc, often intuitively as a reaction to new situations and problems (Griffin, 2004, p. 409).

Another division of changes is presented by Karnouskos (2015), distinguished here by:

- incremental changes - require only minor modifications;

- discontinuous changes - a significant transformation is necessary;

- anticipatory changes - noticed, but without immediate need to react;

- reactive changes - being a direct response of the enterprise to a change in the environment.

Change management is a very contemporary phenomenon. Most enterprises constantly change their activities and organizational culture, because due to technological progress, changes in production techniques, changing customer behaviour, economic changes, and changing activities in the business world, the organization has to keep up with new conditions and requirements. Change management can be seen when an organization decides to change its current mode of business to a new style or model to deal with the rapid changes in the business world, but with profit maximization in mind. The change may concern the organizational structure, organization employees, company technology, production techniques, administration or management change (Hashim 2013), and each of them requires time and the necessary resources (Meißner et al. 2021).

There are many approaches and definitions of change management in an enterprise in the literature. Change management is a set of activities aimed at achieving the expected state in the organization (Brzozowski, Kopczyński 2009 , p. 190). It is also emphasized that change management refers to the creation of flexible management opportunities, as well as quick response to the present and creating such an economic unit that will successfully prosper in the hardly foreseeable future (Brzeziński 2005, p. 18). 
The need for change is difficult to plan, therefore it tends to be reactivity, discontinuity, ad hoc and is a response to the organizational crisis (Nelson 2003). Effective management of change is now seen as a necessity to survive and succeed in today's highly competitive and constantly evolving environment. Despite this, the reported failure rate can be as high as around $70 \%$ of all initiated change programs. It may be suggested that this poor success rate indicates a fundamental lack of an important framework for implementing and managing organizational change (Todnem 2005).

The change management task is not an easy task, as it requires many different competences and skills: business, analytical, political, systemic, personal, and often depends on the participation of various consultants who currently perform change management duties in various organizations. Change management plays an important role in the development of the organization, as it keeps the organization stable and "up-to-date" by examining internal and external changes. Continuous change also provides a solid foundation of a company's value and reputation, and contributes to economic performance. Change management also builds an appropriate organizational culture and a healthy work system in the company. Although change management often uses a top-down approach, i.e. to some extent management dictates the scope and way of introducing changes, it seems necessary due to the need to promote an organizational culture based on change, where at the same time employees perform their activities in an effective and efficient manner. The topdown approach also offers the possibility of better human resource management when employees perceive changes poorly and resistance arises in the organization (Hashim 2013).

Efficient change management means planning, initiating, implementing, controlling and stabilizing change processes both at the enterprise and individual level. Change management assumes constant influencing people, which is difficult for many managers. Change may create or intensify various problems, such as the strategic direction of activities or the need to provide increased support for employees who have difficulty adapting to the new operating conditions.
However, strategic, technological and structural changes, as well as changes in the attitudes and behaviour of personnel, are aimed at the competitiveness and profitability of the enterprise (Teczke, Bespayeva, Bugubayeva 2017).

Managing change to be ultimately effective requires a vision of the target state, without which the change becomes inconsistent and intuitive. Proper definition of the vision of the target state refers not only to the future structures and processes in the organization, but also to the quality maintenance required by decisionmakers, the desired value system or the attitudes of the members of the organization. A key role in this process is played by the change manager, who is a person with very specific character traits and communication skills - sometimes useful only during the transformation of the company (Nadziakiewicz 2015).

It should be noted that organizational changes may refer to the organization as a whole or refer to particular levels of functioning, which requires the use of different strategies and change techniques. These can be changes at the level (Goodstein, Burke 1991):

- people working in the organization,

- organizational structures and systems,

- all activities influencing building a specific organizational climate.

Factors that force the need to introduce organizational changes can generally be classified into two categories (Paton, McCalman 2008, p. 30):

- external factors - inherent in the organization's environment,

- internal factors - inherent in the organization itself.

The observations show that external causes occur much more often and are of primary nature, because it is the market environment and changes taking place in it that impose the necessity of changes on the organizations (enterprises). Internal factors are connected with the necessity of changes in the organization itself. They can be directly related to the development of a given organization, a new market strategy, a change in the company's operating profile or a new vision of the manager / owner regarding the company's operation. It is 
worth noting that these two groups of factors are closely related and most often changes are implemented under the influence of both factors.

The basic problem in the change management process is establishing the correct path of action. The scope and direction of the course of change management require in practice the identification of the factors influencing changes in relation to the change design, personnel, organization and implementation. In order for this process to run correctly, it is appropriate to establish such elements as: organization goals, analysis of the interaction network of individual elements, analysis of the strengths and weaknesses of the organization, the specificity of the enterprise, analysis of possible change scenarios, strategy of operation for the selected solution (Bubel 2016).

One of the basic and best-known change management processes was presented by K. Lewin in 1951 and consisted of three main phases (Düren 2013, p. 10):

- unfreezing - all members of the organization must be aware that something needs to change, and management informs employees about the reasons for the change and the purpose (s) of the process.

- moving - the organization performs the required change activities and determines who is involved, what needs to be done by when and what tools are needed.

- refreezing - this is the time needed to stabilize new methods, structures etc. and to evaluate the actions taken.

In the literature, there are many modifications to the change management process, specifying more general or more detailed stages of change implementation, but they basically emphasize the need to use a process approach to change management.

\section{Methods}

Empirical research should always be preceded by a review of the literature on the subject, so as to be able to confront the achievements to date in a given area of knowledge with the results of own research and conclusions built on their basis. The author reviewed domestic and foreign literature, which allowed to improve the quality of the subsequent empirical research.

The author carried out a survey among 62 micro-enterprises in Poland in May 2021.

The aim of the article was to diagnose and evaluate selected aspects of change management in a microenterprise and to indicate the correlation between change management and the performance of microenterprises.

The research tool was a questionnaire. All the surveyed companies are micro-enterprises, i.e. entities employing from 0 to 9 people. The selection of the research sample was random, therefore the conclusions drawn on the basis of the study should be treated as preliminary conclusions, requiring further confirmation in studies on a larger group of entities.

The analysis of change management in microenterprises was carried out on the basis of 12 questions assessed on the 5-point Likert scale. They were:

A. I believe that organizational changes are
necessary and good for the company
B. I pay attention to communication in the
company before introducing changes
C. I try to adjust the changes to the
organizational goals and strategy of the
company

D. Before introducing a change, we analyse our own possibilities and environmental conditions to make the change as effective as possible

E. Employees are informed and involved in the process of introducing changes

F. We are aware that the changes arouse resistance among employees and we know the methods of eliminating it

G. We try to encourage and motivate employees to participate in the change process

H. Introducing changes in our company is planned over time

I. We know what costs and needs (assets, human resources, etc.) will be related to a given change

J. We always have the knowledge and skills to implement a given change

$\mathrm{K}$. The implementation of changes always takes the form of a planned process 
L. After introducing the change, we evaluate the effectiveness of the changes in relation to the initial plans and draw conclusions for the future

\section{Results}

Changes are an integral part of the company's operations. It can even be said that in the present times of increasing competition, globalization and crises of various causes, changes are more frequent and require more and more attention from the management of the company.

While in large enterprises, managed by professional managers, changes are not only analysed and managed, but often constitute an element of strategic management, in smaller entities the perception of changes may be different. Some companies perceive change only as a threat, and not as an opportunity for a new, better quality.

Change management, in a professional understanding, is the domain of primarily large or medium-sized companies. Small entities are not aware that many activities carried out by owners or managers fall within the definition or in the process of change management. Hence, in order to assess whether change management activities and processes take place in the studied microenterprises, the respondents were presented with a list of questions that they assessed on a 5point Likert scale, i.e. from the answer "I strongly disagree" to the answer "I strongly agree" (Fig. 1). Aspects that, in the author's opinion, may appear / occur in such micro entities were selected for the study.

Figure 1: Assessment of change management activities and processes.

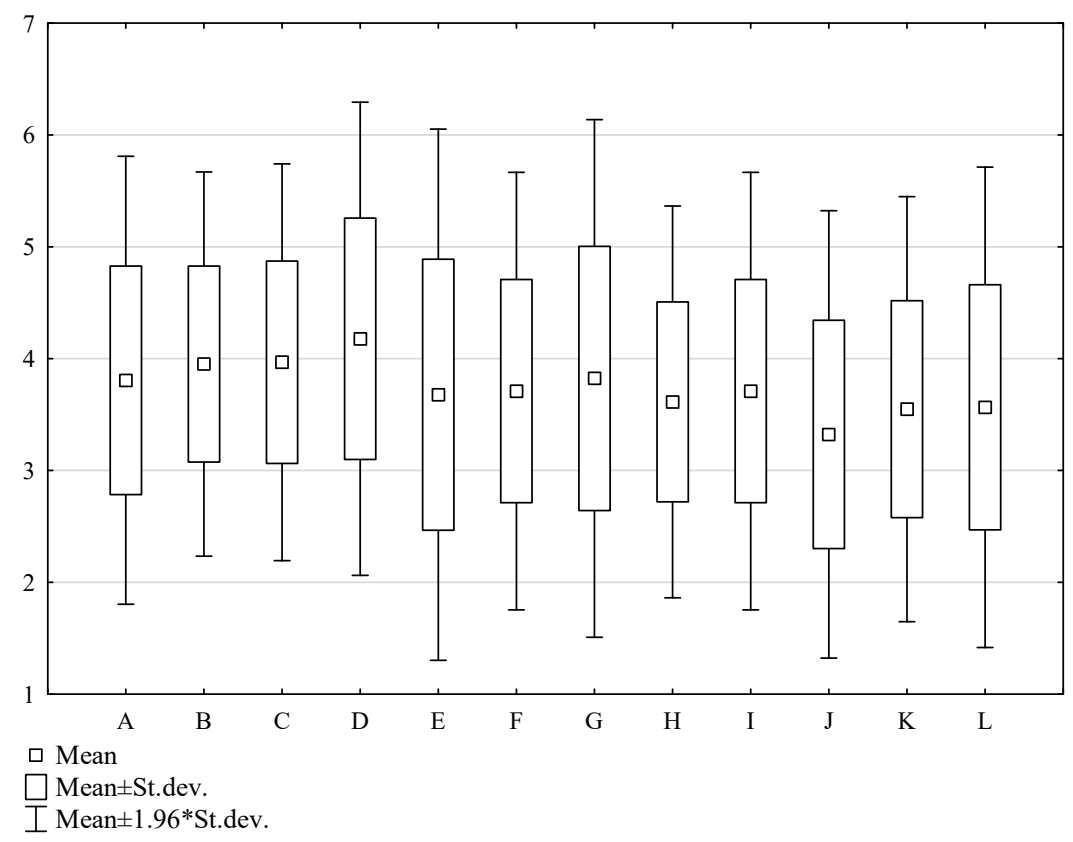

Source: own research

When ranking selected aspects of change management according to the average rating given by the respondents, the item concerning the period of preparation of the change was ranked the highest, when the analysis of own possibilities and environmental conditions was made to make the change as effective as possible (average 4.2 on a 5-point scale). It is also the only question for which the median answer was 5.0. Therefore, one can express the opinion that introducing changes in micro-enterprises is mostly based on rational premises.

Another issue related to change management, which was rated 4.0 by the 
respondents on average, is adjusting changes to the company's goals and strategy. This indicates a certain consistency in the process of introducing changes, which is generally consistent with the long-term planning and vision of the entrepreneur.

The owners of the surveyed companies relatively often also pay attention to communication in the company before introducing changes (average 3.97). In the case of this question, a relatively low level of standard deviation suggests a significant agreement of the answers.

When analysing the assessment of the change management elements, it is clear that many questions rated fairly average by the respondents concern human resource management in relation to change. This indicates that effective implementation of change is not possible without the participation and commitment of all members of the organization.
The lowest scores were assessed by microenterprises relating to the professionalism of change management, i.e. implementing changes in the form of a planned process (average 3.53) and having adequate knowledge and skills to implement a given change (average 3.30). Entrepreneurs confirm that the management of a micro-company is often intuitive and informal, with a low degree of planning.

When trying to define the relationship between the actions of micro-enterprises for change management and business performance, it should be stated that it was achieved in 4 cases (Tab. 1). Thus, a positive, moderate relationship was observed between business performance and the awareness of the need to use human and material resources when managing change, assessing the effectiveness of changes in relation to the initial plans and drawing conclusions for the future.

Table 1. Kendall's Tau correlation analysis $(\mathrm{p}<0.05)$

\begin{tabular}{|c|c|}
\hline & Firm's performance \\
\hline A & $-0,023$ \\
\hline B & $0,176^{\mathrm{i}}$ \\
\hline C & $0,186^{\mathrm{i}}$ \\
\hline D & 0,161 \\
\hline E & 0,132 \\
\hline F & $-0,129$ \\
\hline G & 0,046 \\
\hline H & $-0,044$ \\
\hline I & $0,496^{\mathrm{i}}$ \\
\hline J & 0,148 \\
\hline K & 0,111 \\
\hline L & $0,350^{\mathrm{i}}$ \\
\hline${ }^{\mathrm{i} p}<0.05$ & \\
\hline
\end{tabular}

Source: own research

Statistically significant, but weakly positive, was the correlation between business performance and communication within the company in the process of introducing changes and adapting changes to organizational goals and the company's strategy. 


\section{Conclusion}

Organizational change refers to any transformation occurring in various areas of the organization's functioning, which may occur under the influence of both internal and external factors. It should be noted that nowadays changes in enterprises are constantly taking place, determined by globalization, digitization, shortening the life cycle of products or increasing competition. Organizational changes are the response of companies to the requirements of the environment and are an attempt to increase the effectiveness of the operation of a given company. Adaptation to changing conditions of functioning requires a professional approach of managers to change

\section{References}

Armstrong, M. (2000). Zarządzanie zasobami ludzkimi, Oficyna Ekonomiczna. Kraków: Dom Wydawniczy ABC.

Brzeziński, M. (2005). Proces uczenia się zmian, Przegląd Organizacji, 3, 18.

Brzozowski, M., Kopczyński, T. (2009). Metody zarządzania. Poznań: Wydawnictwo Uniwersytetu Ekonomicznego w Poznaniu.

Bubel, D. (2016). Zarządzanie procesem zmian w aspekcie doskonalenia działalności przedsiębiorstw na przykładzie sieci dealerskich, Zeszyty Naukowe Politechniki Śląskiej, Seria: Organizacja I Zarządzanie, 97, 51-63.

Burnes, B. (2004). Managing Change: A Strategic Approach to Organisational Dynamics, Pearson Education, 318-329.

Clarke, L. (2012). Zarządzanie zmianą. Warszawa: Wydawnictwo Geerthner i Ska.

Düren, P. (2013), Leadership in Academic and Public Libraries. A Time of Change, Chandos Publishing.

Dziadkiewicz, A., Juchniewicz, P. (2013). Koncepcja zarządzania zmianą w organizacji, Prace Naukowe Uniwersytetu Ekonomicznego we Wrocławiu, 277, 15-23.

Goodstein, L.D., Burke, W.W. (1991). Creating successful organization change, Organizational Dynamics, 19(4), 5-17.

Griffin, R.W. (2004). Podstawy zarządzania organizacjami. Warszawa: Wyd. Naukowe PWN. management. This is because activities are undertaken in many areas, which requires a holistic approach.

The research confirmed both the fact that micro-enterprises manage change. Although this management can be described as informal and to a limited extent, the changes are undoubtedly of interest to the owners of micro-enterprises. Moreover, it was possible to confirm that some elements of change management have a positive impact on the performance of a microenterprise.

The limitation of the study is primarily a small research group, therefore the research should be treated as preliminary research.

Hashim, M. (2013). Change Management, International Journal of Academic Research in Business and Social Sciences, 3(7), 658694.

Karnouskos, S. (2015). Effective Change Management in Modern Enterprises, Linneaus University, Sweden, [on-line] [cit.: 2021-06-15]. Retrieved from: https://www.divaportal.org/smash/get/diva2:903428/FULLTE XT01.pdf.

Kulawik-Dutkowska, J. (2016). Teorie zmiany organizacyjnej, Klincewicz, K. (ed.): Zarządzanie, organizacje i organizowanie przegląd perspektyw teoretycznych. Warszawa: Wyd. Naukowe Wydziału Zarządzania Uniwersytetu Warszawskiego, 195-205.

Meißner, M., Jacobs, G., Jagla, P., Sprehe, J. (2021). Model based systems engineering as enabler for rapid engineering change management, Procedia CIRP, 100, 61-66.

Nadziakiewicz, M. (2015). Wybrane aspekty zarządzania zmianą organizacyjną w jednostkach służby zdrowia, Zeszyty Naukowe Politechniki Śląskiej, Seria: Organizacja i Zarządzanie, 79, 205-216.

Nelson, L. (2003). A case study in organizational change: implications for theory, The Learning Organization, 10(1), 18-30.

Olejniczak, K., Nabiałek, K. (2015). Zarządzanie zmianą $\mathrm{W}$ nowoczesnym przedsiębiorstwie, Lemańska-Majdzik, A., Okręglicka, M. (eds.): Dylematy i wyzwania doskonalenia zarządzania organizacjami w zintegrowanej 
Europie, Częstochowa: Wydawnictwo Wydziału Zarządzania Politechniki Częstochowskiej, 17-24

Paton, R., McCalman, J. (2008). Change management. London: SAGE Publications Ltd..

Pszczołowski, T. (1978). Mała encyklopedii prakseologii i teorii organizacji. Wrocław: Zakład Narodowy im. Ossolińskich.

Rieley, J., Clarkson, I. (2001). The impact of change on performance, Journal of Change Management, 2(2), 160-172.

Schermerhorn, J. R. (2008). Zarządzanie, Warszawa: PWE.

Teczke, M., Bespayeva, R. S., Bugubayeva, R. O. (2017). Approaches and models for change management, Jagiellonian Journal of Management, 3, 195-208.

Todnem, R. (2005). Organisational Change Management: A Critical Review, Journal of Change Management, 5(4), 369-380.

\section{Contact}

Karolina Okręglicka, BA.

Faculty of Management

Czestochowa University of Technology

Dąbrowskiego 69

42-201 Częstochowa

Poland

e-mail: ka.okreglicka@gmail.com

Assoc. prof. Maryna Pichugina

Department of Management

National Technical University of Ukraine "KPI"

37, Prosp. Peremohy

03056 Kyiv

Ukraine

e-mail: pichuginam@ukr.net 